\title{
Molecular Pharmacology of Synthetic Cannabinoids: Delineating CB1 Receptor-Mediated Cell Signaling
}

\author{
Kenneth B. Walsh * and Haley K. Andersen \\ Department of Pharmacology, Physiology \& Neuroscience, University of South Carolina, School of Medicine, \\ Columbia, SC 29208, USA; haley.andersen@uscmed.sc.edu \\ * Correspondence: walsh@uscmed.sc.edu
}

Received: 24 July 2020; Accepted: 14 August 2020; Published: 25 August 2020

\begin{abstract}
Synthetic cannabinoids (SCs) are a class of new psychoactive substances (NPSs) that exhibit high affinity binding to the cannabinoid CB1 and CB2 receptors and display a pharmacological profile similar to the phytocannabinoid (-)-trans- $\Delta^{9}$-tetrahydrocannabinol (THC). SCs are marketed under brand names such as $\mathrm{K} 2$ and Spice and are popular drugs of abuse among male teenagers and young adults. Since their introduction in the early 2000s, SCs have grown in number and evolved in structural diversity to evade forensic detection and drug scheduling. In addition to their desirable euphoric and antinociceptive effects, SCs can cause severe toxicity including seizures, respiratory depression, cardiac arrhythmias, stroke and psychosis. Binding of SCs to the CB1 receptor, expressed in the central and peripheral nervous systems, stimulates pertussis toxin-sensitive $G$ proteins $\left(G_{i} / G_{0}\right)$ resulting in the inhibition of adenylyl cyclase, a decreased opening of $\mathrm{N}$-type $\mathrm{Ca}^{2+}$ channels and the activation of $G$ protein-gated inward rectifier (GIRK) channels. This combination of signaling effects dampens neuronal activity in both CNS excitatory and inhibitory pathways by decreasing action potential formation and neurotransmitter release. Despite this knowledge, the relationship between the chemical structure of the SCs and their CB1 receptor-mediated molecular actions is not well understood. In addition, the potency and efficacy of newer SC structural groups has not been determined. To address these limitations, various cell-based assay technologies are being utilized to develop structure versus activity relationships (SAR) for the SCs and to explore the effects of these compounds on noncannabinoid receptor targets. This review focuses on describing and evaluating these assays and summarizes our current knowledge of SC molecular pharmacology.
\end{abstract}

Keywords: CB1 receptors; synthetic cannabinoids; molecular pharmacology; cell signaling assays

\section{Introduction}

The changing legal and social perception of Cannabis sativa highlights the importance of understanding the molecular pharmacology of cannabinoids [1-3]. A major breakthrough in cannabis research came with the isolation and identification of (-)-trans- $\Delta^{9}$-tetrahydrocannabinol (THC) by Gaoni and Mechoulam [4]. THC is the most abundant phytocannabinoid found in Cannabis sativa and the main psychotropic compound in the plant [1,2]. The psychoactive effects of THC result primarily from its binding to the cannabinoid CB1 receptor, a member of the $G$ protein-coupled receptor (GPCR) family of proteins $[5,6]$. CB1 receptors are primarily localized to presynaptic nerve terminals in the central and peripheral nervous system $[7,8]$. Stimulation of the CB1 receptor causes the dissociation of the $\beta \gamma$ subunits of pertussis toxin-sensitive $G$ proteins $\left(G_{i} / G_{0}\right)$ from the $\alpha$ subunit $\left(G_{i} \alpha\right)$. $G_{i} \alpha$ inhibits adenylyl cyclase resulting in a fall in intracellular levels of cAMP [9]. In contrast, $G_{i} \beta \gamma$ causes the opening of $G$ protein-gated inward rectifier $\mathrm{K}^{+}$(GIRK) channels causing a more negative resting membrane potential [10]. This combination of cannabinoid actions brings about an acute inhibition of synaptic neurotransmitter release $[7,11]$. 
Synthetic cannabinoids (SCs) represent a collection of diverse compounds that exhibit high affinity binding to the cannabinoid CB1 and CB2 receptors and display a pharmacological profile similar to that of THC [1-3]. A tetrad of behavioral tests has been used to examine cannabinoid-mediated actions through the CB1 receptor in rodents. This cannabinoid tetrad of behavioral responses encompasses hypothermia, catalepsy, antinociception and a suppression of motor activity. WIN $55,212-2$, the prototypic aminoalkylindole SC, while displaying equal efficacy to THC shows greater potency in the tetrad tests [12,13]. Other aminoalkylindole compounds, such as JWH-018 and AM-2201, show even greater potency in some of the tetrad paradigms. For example, JWH-018 produces nociceptive activity in the rodent tail flick test with a half-maximal effective dose $\left(\mathrm{ED}_{50}\right)$ of less than $0.1 \mu \mathrm{mole} / \mathrm{kg}$ compared with $\mathrm{ED}_{50} \mathrm{~s}$ of approximately 1 and $12 \mu \mathrm{mole} / \mathrm{kg}$ for WIN 55,212-2 and THC, respectively $[13,14]$. Newer SCs including the indazole carboxamides AB-CHIMINACA and AB-PINACA also produce dose-dependent nociception, ring immobility (catalepsy), hypothermia and suppression of movement consistent with their binding to the CB1 receptor [15].

Products containing SCs, sold under brand names such as K2, Spice and Black Mamba, first became available in the early 2000s and have grown in popularity since that time particularly among teenagers and young adults [1,2]. These products contain a mixture of SCs that are sprayed on dried plant material and marketed to suggest a similarity to marijuana. Alternatively, liquid formulations of SCs can be vaporized and inhaled using e-cigarettes or other vaping devices. While the first K2/Spice products contained the SCs JWH-018 and CP 47,497-C8, manufacturers have introduced newer structural classes of SCs (see below) to avoid forensic detection and drug enforcement scheduling. Adverse pharmacological effects reported from SC use include impairment of fine motor skills, increased blood pressure, tachycardia, tremors, respiratory depression, seizures, ataxia, nausea, vomiting, acute kidney injury and death $[1,2]$. Of additional concern, SCs typically produce more adverse psychological effects than those experienced with THC including: impairments of attention and concentration, anxiety, panic, agitation, paranoia, hallucinations, violent or aggressive behavior, short-term memory loss and lack of responsiveness $[16,17]$.

This review provides a brief historical overview of SCs and then describes the molecular pharmacology of the compounds. The review focuses on the cell-based assay technologies that have been utilized to reveal CB1 receptor-mediated effects of the SCs and summarizes the results obtained using these technologies. Readers wishing a more in-depth description of the chemical properties of the SCs, or their neurological/clinical effects, are directed to the appropriate reviews [2,16-18].

\section{Overview of Synthetic Cannabinoids}

Major structural classes of SCs include the naphthoylindoles, phenlacetylindoles, cyclohexylphenols, tetramethylcyclopropyl indoles, indole and indazole carboxamides and quinolinyl esters (Figure 1). The aminoalkylindole class of SCs was developed based on the structure of the nonsteroidal anti-inflammatory drug (NSAID) pravadoline (WIN 48,098) [19].

Structure-activity relationship (SAR) studies carried out by Sterling Winthrop in the late 1980s resulted in the identification of the exemplar CB1/CB2 receptor agonist WIN 55,212-2 [19]. Based on the structure of WIN compounds, John W. Huffman and colleagues at Clemson University synthesized the first series of naphtholylindole cannabinoids (JWH-007, JWH-018, JWH-201, etc.) in the 1990s $[13,20,21]$. These experiments were designed to develop a SAR for the CB1 receptor and to compare the binding properties of the SCs with THC. This was followed by the synthesis of other naphthoylindoles (AM-1220, AM-2201), naphthoylpyrroles (JWH-30, JWH-145) and phenylacetylindole (JWH-203, JWH-250) compounds [13,22]. Thus, in the early 2000s the aminoalkylindoles along with cyclohexylphenols (CP-47,947, CP-55,940) were the most common SCs found in K2/Spice products.

In the period from 2010 to 2020, new groups of chemically distinct cannabinoids appeared on the SC market. These included the tetramethylcyclopropyl indoles UR-144 and XLR-11 (Figure 1). In these compounds, a tetramethylcyclopropyl group is substituted for the naphthoylindole group found in earlier SCs (e.g., JWH-018). In addition, XLR-11 has a fluoro group (see below) added to the terminal 
end of the pentyl side chain of UR-144 (Figure 1). Other classes of SCs including indole (AB-PICA, AB-FUBICA) and indazole (AB-PINACA, MDMB-FUBINACA) carboxamides, as well as quinolinyl esters (BB-22, $\mathrm{PB}-22$ ), were introduced during this time into K2/Spice products. The indole and indazole carboxamides then provided the scaffold for the production of newer chemical moieties $[2,3,18]$. For example, cumylamine SCs (CUMYL-PICA, CUMYL-FUBICA) are derived through substituting the valinamide $(\mathrm{AB})$ or other amino acid group of the indole and indazole carboxamides with a cumylamine. The azaindole SCs (5F-AB-P7AICA, 5F-PCN) have the indazole group replaced with a two nitrogen atom-containing aziandole (Figure 1). Benzimidazole analogs (FUBIMINA, MEPIRAPIM) replace the indole core with a benzimidazole group. The cumylamine, azaindole and benzimidazole SCs represent three of the newer groups identified by the European Monitoring Centre for Drugs and Drug Addiction (EMCDDA) on the NPS drug market [3].

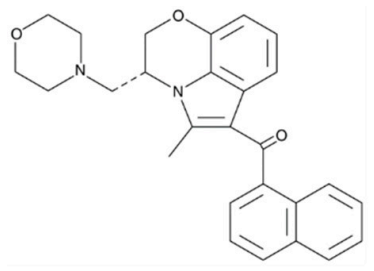

WIN 55,212-2

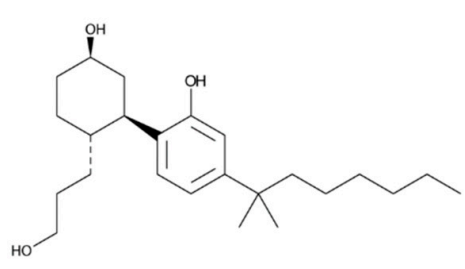

CP 55,940

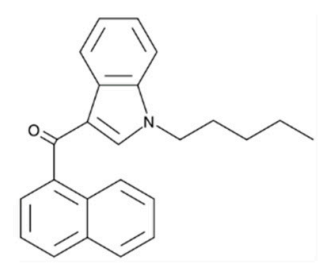

JWH-018

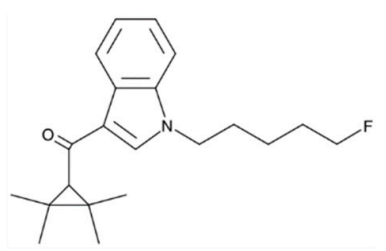

XLR-11
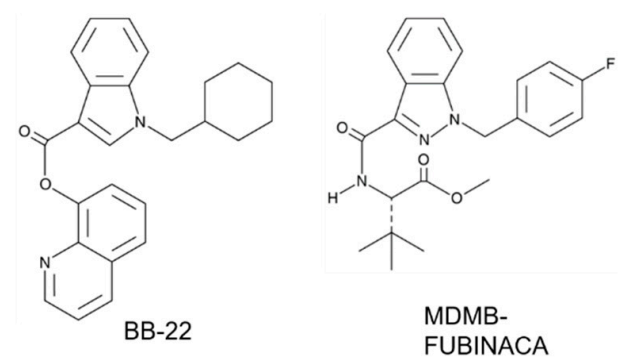

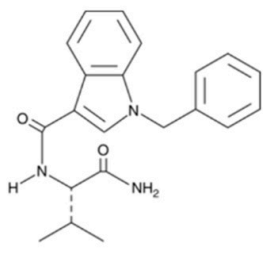

AB-BICA

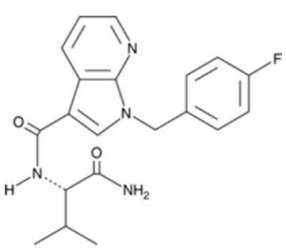

AB-FUB7AICA

Figure 1. Structural classes of synthetic cannabinoids. Chemical structures of WIN 55,212-2 (aminoalkylindole), JWH-018 (naphtholylindole), XLR-11 (tetramethylcyclopropyl), AB-BICA (indole carboxamide), CP 55,940 (cyclohexylphenol), BB-22 (quinolinyl ester), MDMB-FUBINACA (indazole carboxamide) and AB-FUB7AICA (7-azaindole carboxamide).

Stereospecific activity and enhanced cannabinoid receptor affinity with alkyl chain fluorination are two important chemical characteristics of many SCs. Early studies demonstrated that while (+)-WIN 55,212 was active in the mouse tetrad test, its enantiomer (-)-WIN 55,212 lacked activity [12]. HU-210, the (-) enantiomer of 11-hydroxy $\Delta^{8}$-THC- dymethylheptyl, is a full agonist at the CB1 receptor [23]. In contrast, the (+) enantiomer (HU-211) has limited cannabinoid activity [24]. Recent studies have also demonstrated stereospecific effects of newer SCs. For some of the carboxamide-type SCs (AB-FUBINACA, AMB-CHMINACA), the (R)-enantiomer shows increased potency at the CB1 receptor compared to the (S)-enantiomer $[25,26]$. Terminal fluorination of pentylindole SCs is a popular chemical modification found in K2/Spice products. Substitution of a fluorine atom for hydrogen is found in AM-2201 (terminal fluorination of JWH-018) and results in greater CB1 receptor binding affinity [27]. Consistent with this, the fluorinated analogs of the SCs UR-144, PB-22 and APICA (XLR-11, 5F-PB-22 and STS-135, respectively) show increased CB1 receptor potency [28]. Surprisingly, these terminal fluorinated SCs show no greater potency compared with the nonfluorinated compounds when tested in rats for changes in body temperature and heart rates [28].

\section{CB1 Receptor-Mediated Cell Signaling}

Binding of cannabinoids to the CB1 receptor produces a characteristic group of psychotropic effects including euphoria, enhancement of sensory perception, antinociception, appetite stimulation 
and impairment of memory. As is the case with other Class A GPCRs, the CB1 receptor contains seven transmembrane domains and an intracellular domain that interacts with the $G_{i}$ protein heterotrimer (Figure 2A) $[6,29,30]$. In the CNS and peripheral nervous systems, the CB1 receptor predominately couples to the $G$ proteins $G_{i}$ ad $G_{0}$ (Figure $2 B$ ). However, under some conditions, $C B 1$ receptor-mediated stimulation of $G_{s}$ and $G_{q}$ has also been observed (see Section 5) [31,32]. $G_{i}$ inhibits the production of cAMP and the opening of $\mathrm{Ca}^{2+}$ channels $(\mathrm{N} \& \mathrm{P} / \mathrm{Q}$ type) while activating GIRK channels $[9,10]$. These acute actions occur within seconds of cannabinoid binding to the CB1 receptor. This is followed by receptor phosphorylation (by $G$ protein receptor kinase [GRK]) that recruits $\beta$-arrestin1 ( $\beta$ arr1) and $\beta$-arrestin2 ( $\beta$ arr2) to the receptor and results in CB1 receptor desensitization and internalization [33-35]. Both $G_{i}$ and $\beta$-arrestin can also stimulate mitogen-activated protein kinases (MAPKs), including the extracellular signal-regulated kinases (ERK1/2), bringing about additional cellular effects [36-38]. Finally, cannabinoids can act through membrane receptors (off targets) other than the CB1 and CB2 receptors. Endocannabinoids such as anandamide ( $\mathrm{N}$-arachidonoylethanolamine [AEA]) and 2-arachidonoylglycerol (2AG) bind to, and activate, inotropic transient receptor potential (TRP) channels causing cell membrane potential depolarization and $\mathrm{Ca}^{2+}$ influx (Figure 2B) [39,40]. In addition, the deorphanized GPCRs GPR55 and GPR18 are also targets of endocannabinoids [41,42].

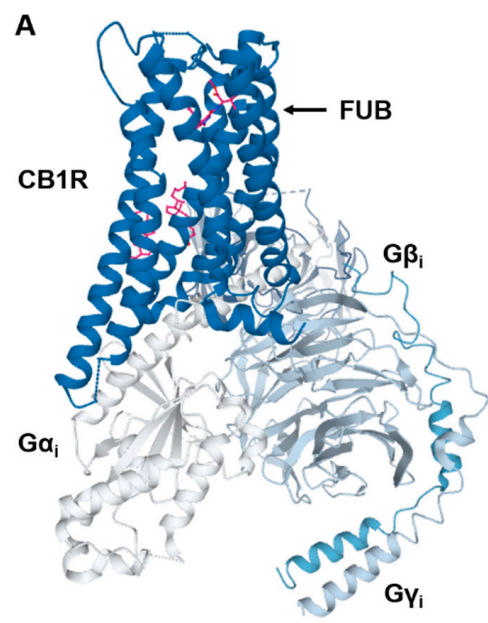

B

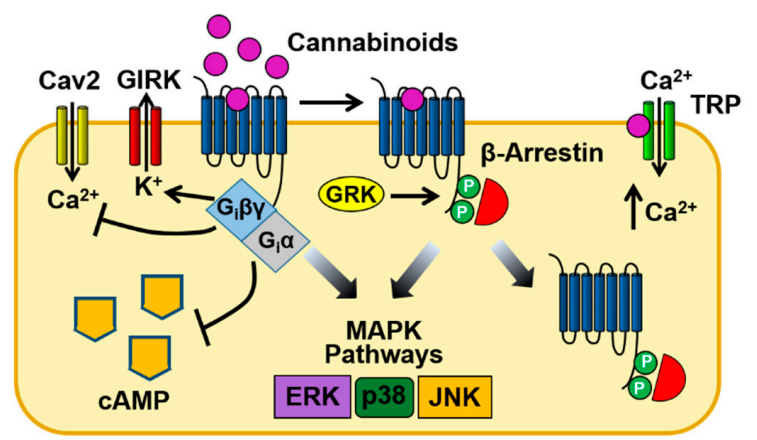

Figure 2. Cannabinoid CB1 receptor structure and signaling. (A) Structural model of the CB1 receptor $(\mathrm{CB} 1 \mathrm{R})-\mathrm{G}_{\mathrm{i}}$ protein complex obtained from cryoelectron microscopy. The binding site for MDMB-FUBINACA (FUB) is indicated by the magenta SC structure. The CB1- $\mathrm{G}_{\mathrm{i}}$ receptor complex structure was obtained from the Protein Data Bank (code 6N4B). (B) Binding of SCs to the CB1 receptor stimulates both neuronal $\mathrm{G}_{\mathrm{i}} / \mathrm{G}_{\mathrm{o}}$ and $\beta$-arrestin signaling pathways (see text for description). In addition, activation of inotropic transient receptor potential (TRP) channels by cannabinoids causes $\mathrm{Ca}^{2+}$ influx into the neuron.

Accumulating evidence now suggests that SCs function as biased ligands at CB1 receptors. The concept of biased receptor agonism (or functional selectivity) was proposed as a mechanism for explaining how ligands which bind to the same GPCR can produce differing pharmacological actions [43]. It was hypothesized that biased receptor agonists can stabilize GPCR conformations that couple to some signaling pathways, but not to others. The strongest support for the biased agonism model has come from studies with the $\mu$-opioid receptor where ligands that stimulate $G$ protein-dependent pathways have beneficial analgesic actions while ligands that recruit $\beta$-arrestins have adverse actions (such as respiratory depression) [44]. Oliceridine (TRV130), a biased $\mu$-opioid receptor agonist, displays an efficacy equal to that of morphine for $\mathrm{G}_{i}$ stimulation, but does not promote morphine-mediated $\beta$-arrestin recruitment and $\mu$-opioid receptor internalization [45]. Experimental evidence for SC biased signaling is provided in Table 1 and described in Section 5. 
Table 1. Summary of the potencies $\left(\mathrm{EC}_{50}\right)(\mathrm{in} \mathrm{nM})$ and efficacies $\left(\mathrm{E}_{\max }\right)^{*}$ of synthetic cannabinoids $(\mathrm{GCs})$ determined using cell assays.

\begin{tabular}{|c|c|c|c|c|c|c|c|c|c|c|c|}
\hline \multirow{2}{*}{$\begin{array}{c}\text { Synthetic } \\
\text { Cannabinoids } \\
\text { Aminoalkylindoles } \\
\text { Cyclohexylphenols }\end{array}$} & \multicolumn{2}{|c|}{ GTP Binding } & \multicolumn{2}{|c|}{ cAMP } & \multicolumn{2}{|c|}{$\beta$-arrestin2 } & \multicolumn{2}{|c|}{ GIRK Channel } & \multirow[t]{2}{*}{ Cells } & \multirow[t]{2}{*}{ Assay } & \multirow[t]{2}{*}{ Ref } \\
\hline & $E C_{50}$ & $\begin{array}{c}E_{\max } \\
(\%)\end{array}$ & $E C_{50}$ & $\begin{array}{c}E_{\max } \\
(\%)\end{array}$ & $E C_{50}$ & $\begin{array}{c}E_{\max } \\
(\%)\end{array}$ & $E C_{50}$ & $\begin{array}{c}E_{\max } \\
(\%)\end{array}$ & & & \\
\hline \multirow[t]{12}{*}{ WIN $55,212-2$} & 100 & 217 & & & & & & & HEK293 & {$\left[{ }^{35} \mathrm{~S}\right] \mathrm{GTP} \gamma \mathrm{S}$} & [46] \\
\hline & & & 32 & $65 \pm 5^{\mathrm{a}}$ & & & & & HEK293 & GloSensor & [47] \\
\hline & & & 13 & $70 \pm 4^{\mathrm{b}}$ & & & & & HEK293 & BRET & [48] \\
\hline & & & 5 & $64 \pm 6^{\mathrm{a}}$ & & & & & HEK293 & GloSensor & [49] \\
\hline & & & 46 & $114 \pm 5^{c}$ & & & & & HEK293 & BRET & [50] \\
\hline & & & 47 & $113^{c}$ & & & & & HEK293 & HitHunter & [51] \\
\hline & & & 7.6 & $92 \pm 3^{c}$ & 1288 & & & & HEK293 & BRET & [52] \\
\hline & & & 14 & $107 \pm 1^{c}$ & 182 & $89 \pm 2^{c}$ & & & $\mathrm{CHO}$ & Pathfinder & [53] \\
\hline & & & & & 570 & $59 \pm 13$ & & & Neurons $^{\mathrm{d}}$ & BRET & [54] \\
\hline & & & & & & & 27 & $100^{\mathrm{e}}$ & AtT20 & MPSD & [55] \\
\hline & & & & & & & 282 & $100^{\mathrm{e}}$ & AtT20 & MPSD & [28] \\
\hline & & & & & & & 309 & $100^{\mathrm{e}}$ & AtT20 & MPSD & [56] \\
\hline \multirow[t]{11}{*}{ CP-55,940 } & 17 & 163 & & & & & & & HEK293 & {$\left[{ }^{35} \mathrm{~S}\right] \mathrm{GTP} \gamma \mathrm{S}$} & [57] \\
\hline & 8 & $199^{b}$ & 320 & $47 \pm 8^{\mathrm{a}}$ & & & & & HEK293 & GloSensor & [47] \\
\hline & 0.4 & $95 \pm 3$ & & & & & & & HEK293 & {$\left[{ }^{35} \mathrm{~S}\right] \mathrm{GTP} \gamma \mathrm{S}$} & [46] \\
\hline & & & 0.3 & 100 & & & & & $\mathrm{CHO}$ & HTRF & [58] \\
\hline & & & 8 & $58 \pm 3^{b}$ & & & & & HEK293 & BRET & [48] \\
\hline & & & 0.6 & 100 & 178 & $57 \pm 3^{c}$ & & & HEK293 & BRET & [52] \\
\hline & & & 0.2 & $100 \pm 3^{c}$ & 11 & $95 \pm 2^{c}$ & & & $\mathrm{CHO}$ & Pathfinder & [53] \\
\hline & & & & & 138 & $49 \pm 2^{c}$ & & & HEK293 & BRET & [50] \\
\hline & & & & & 350 & $86 \pm 4$ & & & Neurons $^{\mathrm{d}}$ & BRET & [54] \\
\hline & & & & & & & 23 & $100^{c}$ & AtT20 & MPSD & [59] \\
\hline & & & & & & & 17 & $100^{c}$ & AtT20 & MPSD & [60] \\
\hline
\end{tabular}


Table 1. Cont.

\begin{tabular}{|c|c|c|c|c|c|c|c|c|c|c|c|}
\hline \multirow{2}{*}{$\begin{array}{c}\begin{array}{c}\text { Synthetic } \\
\text { Cannabinoids }\end{array} \\
\text { Naphtholylindoles }\end{array}$} & \multicolumn{2}{|c|}{ GTP Binding } & \multicolumn{2}{|c|}{ cAMP } & \multicolumn{2}{|c|}{$\beta$-arrestin2 } & \multicolumn{2}{|c|}{ GIRK Channel } & \multirow[t]{2}{*}{ Cells } & \multirow[t]{2}{*}{ Assay } & \multirow[t]{2}{*}{ Ref. } \\
\hline & $\mathrm{EC}_{50}$ & $\begin{array}{l}E_{\max } \\
(\%)\end{array}$ & $E C_{50}$ & $\begin{array}{c}E_{\max } \\
(\%)\end{array}$ & $E C_{50}$ & $\begin{array}{c}E_{\max } \\
(\%)\end{array}$ & $E C_{50}$ & $\begin{array}{c}E_{\max } \\
(\%)\end{array}$ & & & \\
\hline AM-1221 & 17 & $163^{c}$ & & & & & & & HEK293 & {$\left[{ }^{35} \mathrm{~S}\right] \mathrm{GTP} \gamma \mathrm{S}$} & [57] \\
\hline \multirow[t]{2}{*}{ AM-2201 } & & & & & 24 & $99^{f}$ & & & HEK293 & NanoBiT & [61] \\
\hline & & & & & & & 37 & $111 \pm 6^{\mathrm{e}}$ & AtT20 & MPSD & [28] \\
\hline \multirow[t]{5}{*}{ JWH-018 } & 0.7 & $102 \pm 10$ & 1.7 & $90 \pm$ & 78 & $116 \pm 16$ & & & $\mathrm{CHO}$ & ${ }^{3} \mathrm{H}-\mathrm{cAMP}$ & [62] \\
\hline & & & & & 41 & $99^{f}$ & & & HEK293 & NanoBiT & [61] \\
\hline & & & 16 & $64 \pm 3$ & & & & & HEK293 & BRET & [48] \\
\hline & & & & & 37 & $102^{\mathrm{f}}$ & & & HEK293 & NanoBiT & [63] \\
\hline & & & & & & & 18 & $116^{\mathrm{b}}$ & AtT20 & MPSD & [28] \\
\hline \multirow[t]{2}{*}{ JWH-122 } & & & 3 & $102^{\mathrm{c}}$ & & & & & $\mathrm{CHO}$ & HTRF & [58] \\
\hline & & & & & 72 & & & & HEK293 & NanoLuc & [64] \\
\hline N-(5-chloropentyl) & & & & & 74 & $289^{c}$ & & & HEK293 & NanoBiT & [61] \\
\hline N-(5-bromopentyl) & & & & & 284 & $261^{c}$ & & & HEK293 & NanoBiT & [61] \\
\hline N-(5-I=iodopentyl) & & & & & 215 & $152^{c}$ & & & HEK293 & NanoBiT & [61] \\
\hline \multirow[t]{3}{*}{ JWH-210 } & 116 & 287 & & & & & & & HEK293 & {$\left[{ }^{35} \mathrm{~S}\right] \mathrm{GTP} \gamma \mathrm{S}$} & [57] \\
\hline & & & & & 25 & & & & HEK293 & NanoLuc & [64] \\
\hline & & & 111 & $98^{\mathrm{c}}$ & & & & & $\mathrm{CHO}$ & HTRF & [58] \\
\hline $\begin{array}{l}\text { Tetramethylcyclo- } \\
\text { propyls }\end{array}$ & $\mathrm{EC}_{50}$ & $\begin{array}{l}E_{\max } \\
(\%)\end{array}$ & $E C_{50}$ & $\begin{array}{c}E_{\max } \\
(\%)\end{array}$ & $E C_{50}$ & $\begin{array}{c}E_{\max } \\
(\%)\end{array}$ & $E C_{50}$ & $\begin{array}{c}E_{\max } \\
(\%)\end{array}$ & & & \\
\hline UR-144 & & & & & 426 & & & & HEK293 & NanoLuc & [65] \\
\hline
\end{tabular}


Table 1. Cont.

\begin{tabular}{|c|c|c|c|c|c|c|c|c|c|c|c|}
\hline \multirow{2}{*}{$\begin{array}{c}\text { Synthetic } \\
\text { Cannabinoids } \\
\text { Tetramethylcyclo- } \\
\text { propyls cont. }\end{array}$} & \multicolumn{2}{|c|}{ GTP Binding } & \multicolumn{2}{|c|}{ cAMP } & \multicolumn{2}{|c|}{$\beta$-arrestin2 } & \multicolumn{2}{|c|}{ GIRK Channel } & \multirow[t]{2}{*}{ Cells } & \multirow[t]{2}{*}{ Assay } & \multirow[t]{2}{*}{ Ref. } \\
\hline & $\mathrm{EC}_{50}$ & $\begin{array}{l}E_{\max } \\
(\%)\end{array}$ & $E C_{50}$ & $\begin{array}{l}E_{\max } \\
(\%)\end{array}$ & $E C_{50}$ & $\begin{array}{l}E_{\max } \\
(\%)\end{array}$ & $E C_{50}$ & $\begin{array}{c}E_{\max } \\
(\%)\end{array}$ & & & \\
\hline UR-144 & & & & & & & 421 & $94 \pm 4^{\mathrm{e}}$ & AtT20 & MPSD & [28] \\
\hline \multirow[t]{4}{*}{ XLR-11 } & & & & & & & 98 & $110^{\mathrm{e}}$ & AtT20 & MPSD & [28] \\
\hline & & & 3981 & $65 \pm 5^{\mathrm{a}}$ & & & & & HEK293 & GloSensor & [47] \\
\hline & & & 25 & $107 \pm 2^{\mathrm{c}}$ & 389 & $88 \pm 2^{c}$ & & & HEK293 & BRET & [50] \\
\hline & & & 63 & $63 \pm 2$ & & & & & HEK293 & BRET & [48] \\
\hline $\begin{array}{l}\text { Indole \& Indozole } \\
\text { Carboxamides }\end{array}$ & $E C_{50}$ & $\begin{array}{l}E_{\max } \\
(\%)\end{array}$ & $E C_{50}$ & $\begin{array}{l}E_{\max } \\
(\%)\end{array}$ & $E C_{50}$ & $E_{\max }$ & $E C_{50}$ & $\begin{array}{l}E_{\max } \\
(\%)\end{array}$ & & & \\
\hline \multirow[t]{6}{*}{ AB-CHMINACA } & 7.4 & 205 & & & & & & & HEK293 & {$\left[{ }^{35} \mathrm{~S}\right] \mathrm{GTP} \gamma \mathrm{S}$} & [66] \\
\hline & & & 0.28 & & & & & & $\mathrm{CHO}$ & HitHunter & [67] \\
\hline & & & 0.95 & $100 \pm 4^{c}$ & 30.9 & $110 \pm 4$ & & & HEK293 & BRET & [50] \\
\hline & & & 251 & $51 \pm 2^{b}$ & & & & & HEK293 & GloSensor & [47] \\
\hline & & & & & 3.45 & $390.5^{\mathrm{f}}$ & & & HEK293 & NanoBiT & [63] \\
\hline & & & & & & & 7.8 & $142^{c}$ & AtT20 & MPSD & [60] \\
\hline $\begin{array}{l}\text { ADB-CHMINACA } \\
\text { (MAB-CHMINACA) }\end{array}$ & & & & & .34 & $262.6^{f}$ & & & HEK293 & NanoBiT & [63] \\
\hline \multirow[t]{5}{*}{ AB-PINACA } & 71 & 192 & & & & & & & HEK293 & {$\left[{ }^{35} \mathrm{~S}\right] \mathrm{GTP} \gamma \mathrm{S}$} & [66] \\
\hline & & & 79.4 & $69 \pm 3^{b}$ & & & & & HEK293 & GloSensor & [47] \\
\hline & & & & & 19 & $288^{\mathrm{e}}$ & & & HEK293 & NanoBit & [61] \\
\hline & & & & & & & 1.2 & $103 \pm 4^{\mathrm{e}}$ & AtT20 & MPSD & [59] \\
\hline & & & & & & & 6.5 & $142 \pm 15^{c}$ & AtT20 & MPSD & [60] \\
\hline \multirow[t]{4}{*}{ 5F-AB-PINACA } & 2.45 & $102 \pm 7$ & & & & & & & HEK293 & {$\left[{ }^{35} \mathrm{~S}\right] \mathrm{GTP} \gamma \mathrm{S}$} & [46] \\
\hline & & & & & 66 & $267^{f}$ & & & HEK293 & NanoBiT & [61] \\
\hline & & & & & & & 0.48 & $94 \pm 6^{c}$ & AtT20 & MPSD & [59] \\
\hline & & & & & & & 2.8 & $132 \pm 9^{c}$ & AtT20 & MPSD & [60] \\
\hline 5F-ADB-PINACA & & & & & & & 0.24 & $91 \pm 7^{c}$ & AtT20 & MPSD & [59] \\
\hline
\end{tabular}


Table 1. Cont.

\begin{tabular}{|c|c|c|c|c|c|c|c|c|c|c|c|}
\hline \multirow[t]{2}{*}{$\begin{array}{c}\text { Synthetic } \\
\text { Cannabinoids }\end{array}$} & \multicolumn{2}{|c|}{ GTP Binding } & \multicolumn{2}{|c|}{ cAMP } & \multicolumn{2}{|c|}{$\beta$-arrestin2 } & \multicolumn{2}{|c|}{ GIRK Channel } & \multirow{2}{*}{$\begin{array}{c}\text { Cells } \\
\text { HEK293 }\end{array}$} & \multirow{2}{*}{$\begin{array}{c}\text { Assay } \\
\text { NanoBiT }\end{array}$} & \multirow{2}{*}{$\begin{array}{l}\text { Ref. } \\
\text { [63] }\end{array}$} \\
\hline & & & & & 2.8 & $308^{f}$ & & & & & \\
\hline \multirow[t]{2}{*}{ ADB-FUBICA } & & & & & & & 2.6 & $113 \pm 8^{c}$ & AtT20 & MPSD & [59] \\
\hline & & & & & 12.3 & $314^{\mathrm{f}}$ & & & HEK293 & NanoBiT & [61] \\
\hline 5F-CUMYL-PINACA & & & 0.5 & $107 \pm 6^{c}$ & 16.9 & $97 \pm 7$ & & & HEK293 & BRET & [50] \\
\hline \multirow[t]{5}{*}{ AB-FUBINACA } & & & 0.79 & $116 \pm 4^{c}$ & 33 & $107 \pm 4^{c}$ & & & HEK293 & BRET & [50] \\
\hline & & & 1.36 & & & & & & $\mathrm{CHO}$ & ${ }^{3} \mathrm{H}-\mathrm{cAMP}$ & [68] \\
\hline & & & & & 16 & $324^{\mathrm{f}}$ & & & HEK293 & NanoBiT & [61] \\
\hline & & & & & & & 1.8 & $108 \pm 7^{c}$ & AtT20 & MPSD & [59] \\
\hline & & & & & & & 2.1 & $151 \pm 14^{\mathrm{c}}$ & AtT20 & MPSD & [60] \\
\hline \multirow[t]{2}{*}{ ABD-FUBINACA } & & & & & 0.69 & $339^{f}$ & & & HEK293 & NanoBiT & [61] \\
\hline & & & & & & & 1.20 & $152 \pm 11^{\mathrm{c}}$ & AtT20 & MPSD & [59] \\
\hline \multirow[t]{4}{*}{ 5F-AMB-PINACA } & 1.3 & $96 \pm 8^{c}$ & & & & & & & HEK293 & {$\left[{ }^{35} \mathrm{~S}\right] \mathrm{GTP} \gamma \mathrm{S}$} & [46] \\
\hline & & & 0.6 & $98 \pm 1^{c}$ & 30 & $100 \pm 2$ & & & HEK293 & BRET & [50] \\
\hline & & & & & 15 & $259^{f}$ & & & HEK293 & NanoBiT & [63] \\
\hline & & & & & & & 1.9 & $109 \pm 3^{c}$ & AtT20 & MPSD & [59] \\
\hline \multirow[t]{3}{*}{ 5F-MDMB-PINACA } & 0.29 & $111 \pm 9^{c}$ & & & & & & & HEK293 & {$\left[{ }^{35} \mathrm{~S}\right] \mathrm{GTP} \gamma \mathrm{S}$} & [46] \\
\hline & & & & & 0.84 & $319^{\mathrm{f}}$ & & & HEK293 & NanoBiT & [63] \\
\hline & & & & & 1.78 & $331^{\mathrm{f}}$ & & & HEK293 & NanoBiT & [26] \\
\hline \multirow[t]{3}{*}{ MDMB-CHMICA } & & & 0.14 & & & & & & $\mathrm{CHO}$ & HitHunter & [67] \\
\hline & & & 0.7 & $117 \pm 4^{\mathrm{c}}$ & 32 & $108 \pm 1$ & & & HEK293 & BRET & [50] \\
\hline & & & & & 1.77 & $285^{\mathrm{f}}$ & & & HEK293 & NanoBiT & [63] \\
\hline AMB-CHMINACA & & & & & 3.91 & $360^{\mathrm{f}}$ & & & HEK293 & NanoBiT & [63] \\
\hline
\end{tabular}


Table 1. Cont.

\begin{tabular}{|c|c|c|c|c|c|c|c|c|c|c|c|}
\hline \multirow{2}{*}{$\begin{array}{c}\text { Synthetic } \\
\text { Cannabinoids } \\
\text { Indole \& Indozole } \\
\text { Carboxamides cont. }\end{array}$} & \multicolumn{2}{|c|}{ GTP Binding } & \multicolumn{2}{|c|}{ cAMP } & \multicolumn{2}{|c|}{$\beta$-arrestin2 } & \multicolumn{2}{|c|}{ GIRK Channel } & \multirow[t]{2}{*}{ Cells } & \multirow[t]{2}{*}{ Assay } & \multirow[t]{2}{*}{ Ref. } \\
\hline & $E C_{50}$ & $\begin{array}{c}E_{\max } \\
(\%)\end{array}$ & $E C_{50}$ & $\begin{array}{c}E_{\max } \\
(\%)\end{array}$ & $E C_{50}$ & $\begin{array}{l}E_{\max } \\
(\%)\end{array}$ & $E C_{50}$ & $\begin{array}{c}E_{\max } \\
(\%)\end{array}$ & & & \\
\hline MDMB-CHMINACA & & & & & 0.78 & $227^{f}$ & & & HEK293 & NanoBiT & [63] \\
\hline MDMB-FUBICA & & & 1.0 & $108 \pm 5^{c}$ & 43 & $104 \pm 2$ & & & HEK293 & BRET & [50] \\
\hline \multirow[t]{3}{*}{ MDMB-FUBINACA } & 0.27 & 75 & & & & & & & HEK293 & {$\left[{ }^{35} \mathrm{~S}\right] \mathrm{GTP} \gamma \mathrm{S}$} & [46] \\
\hline & & & 0.65 & 216 & & & & & $\mathrm{CHO}$ & LanceUltra & [69] \\
\hline & & & & & 0.36 & $241^{\mathrm{f}}$ & & & HEK293 & NanoBit & [63] \\
\hline \multirow[t]{2}{*}{ 5F-MDMB-PICA } & & & 0.17 & $109 \pm 7$ & 20 & $111 \pm 4$ & & & HEK293 & BRET & [50] \\
\hline & & & 0.63 & $60 \pm 4^{\mathrm{b}}$ & & & & & HEK293 & BRET & [48] \\
\hline
\end{tabular}

* - $\mathrm{EC}_{50 \mathrm{~s}}$ were normalized as indicated by ${ }^{\text {a-f }}$ (below); a - compared to $65 \%$ inhibition with WIN 55,212-2; b - percent of control measurements; $\mathrm{c}-$ maximal effect compared to CP55,940 $(100 \%) ; \mathrm{d}$ - striatal medium spiny projection neurons; e - maximal effect compared to WIN 55,212-2 (100\%); $\mathrm{f}$ - maximal effect compared to JWH-018 (100\%); BRET = bioluminescence resonance energy transfer; MPSD = membrane potential-sensitive dye; HTRF = homogeneous time-resolved fluorescence; NanoBiT = nanobinary technology assay; NanoLuc = nanoluciferase reporter assay. 


\section{CB1 Receptor Signal Transduction Assays}

While SCs activate a variety of cell signaling pathways, the relationship between the chemical structure of the SCs and their CB1 receptor-mediated molecular actions is only beginning to be explored. In addition, the potency $\left(\mathrm{EC}_{50}\right)$ and efficacy $\left(\mathrm{E}_{\max }\right)$ of new structural groups of SCs are not known. As described below, numerous cell-based methodologies are being utilized to study the molecular signaling of the SCs and to establish SAR for SCs on effector pathways (see Figure 3).
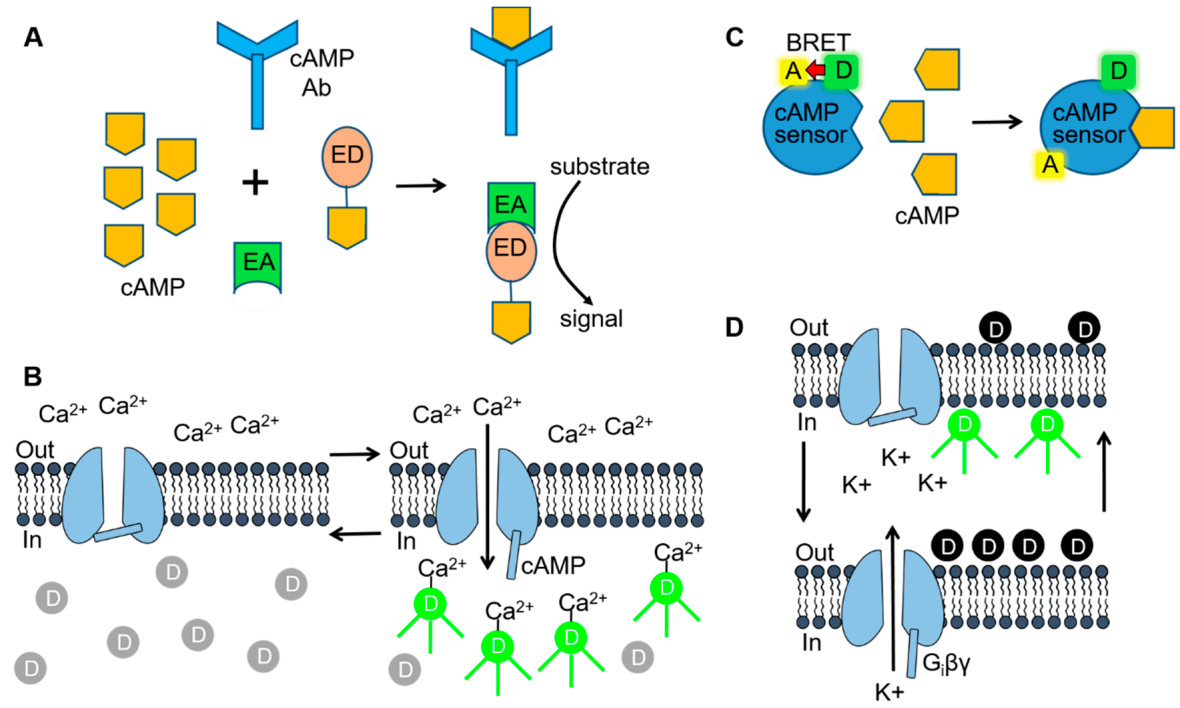

Figure 3. Cell-based assay technologies used for delineating SC-mediated signaling. (A) Fragment complementation assays consist of inactive enzyme donor (ED) and enzyme acceptor (EA) components that form an active enzyme when combined. For measuring $3^{\prime}, 5^{\prime}$-adenosine monophosphate (cAMP), the ED consists of an inactive fragment of $\beta$-galactosidase that is conjugated to cAMP. When cellular cAMP levels are low or absent, the conjugated cAMP is sequestered by the cAMP antibody and no active enzyme is formed. In the presence of high levels of cAMP (as shown), the ED-cAMP conjugate is free to combine with the EA. $\beta$-galactosidase activity is then be detected by adding a substrate that is converted to a fluorescent or luminescent signal. (B) Cyclic nucleotide-gated (CNG) channel cAMP assay. Opening of CNG channels during elevations in intracellular cAMP allows $\mathrm{Ca}^{2+}$ to enter the cell and bind to $\mathrm{Ca}^{2+}$-sensitive fluorescent dye molecules. (C) Bioluminescence resonance energy transfer (BRET) assays use a biosensor consisting of a BRET donor (D) and acceptor (A) pair. The BRET CAMP sensor consists of a cAMP binding protein coupled to the BRET donor, Renilla luciferase (RLuc) and acceptor, yellow fluorescent protein (YFP). Binding of cAMP to the sensor (as shown) results in a conformational change and a loss of BRET intensity. (D) G protein-gated inward rectifier (GIRK) channel fluorescent membrane potential-sensitive dye (MPSD) assay. Hyperpolarization/depolarization of the cell resting membrane potential (left \& right arrows), resulting from $G_{i}$ protein $\beta \gamma$ subunit $\left(G_{i} \beta \gamma\right)$ opening/closing of the GIRK channels, alters the distribution of MPSD molecules across the plasma membrane and thus the fluorescent signal. Figure 3A [70] was adapted with permission of Cambridge University Press through PLSclear. Figure 3C,D [71] were reproduced by permission from BMG Labtech and Taylor \& Francis Ltd. (www.tandfonline.com), respectively.

\subsection{GTP Binding}

The $\left[{ }^{35} \mathrm{~S}\right] \mathrm{GTP} \gamma \mathrm{S}$ binding assay measures the level of $\mathrm{G}$ protein activation following agonist binding to the CB1 receptor. In the assay $\left.{ }^{35} \mathrm{~S}\right] \mathrm{GTP} \gamma \mathrm{S}$ replaces endogenous GTP and binds to the G $\alpha$ subunit following receptor activation to form a G $\alpha-\left[{ }^{35} S\right] G T P \gamma S$ complex. Since the $\gamma$-thiophosphate bond is resistant to hydrolysis by the GTPase of $G \alpha$, the $G$ protein is prevented from reassembling into the $\mathrm{G} \alpha \beta \gamma$ heterotrimer. As a result, the $\left[{ }^{35} \mathrm{~S}\right] \mathrm{GTP} \gamma \mathrm{S}$-labeled $\mathrm{G} \alpha$ subunits accumulate and can be assayed by measuring the incorporation of $\left[{ }^{35} \mathrm{~S}\right] \mathrm{GTP} \gamma \mathrm{S}$ with a scintillation counter. Since the G $\alpha$ subunits remain associated with the plasma membrane, cells expressing the CB1 receptor are treated with a SC 
or control solution, lysed and their membranes collected using filtration. The relative change in the amount of $G \alpha-\left[{ }^{35} S\right] G T P \gamma S$ protein, often expressed as a percent increase over basal binding, is then determined by measuring the radioactivity retained on the filter. Although the assay measures the degree of $\left[{ }^{35} \mathrm{~S}\right] \mathrm{GTP} \gamma \mathrm{S}$ binding, it is very useful for quantifying CB1 receptor activation, and thus for determining the potency and efficacy of the SCs $[46,47,57,66]$. Certainly, the major drawback to this procedure is the inconvenience and cost associated with the handling of radioactive reagents.

\section{2. cAMP Inhibition}

For most cAMP assay protocols, intracellular levels of cAMP are measured in CB1 receptor expressing cells during treatment with the adenylyl cyclase stimulator forskolin (FORS) (with or without the phosphodiesterase inhibitor isobutyl methyl xanthine [IBMX]). These results are then compared with those obtained during the addition of a SC along with FORS and IBMX. Two general methodologies are used in these assays to measure intracellular cAMP. In the first, cAMP levels are measured postexperimentally following cell lysis and the collection of the soluble fraction. One major advantage of these assays is that cAMP can be measured in a variety of cell types and tissue samples. For the most part, these assays are available commercially as kits that use a specific antibody (anti-cAMP $\mathrm{Ab}$ ) that recognizes both intracellular cAMP and an exogenous cAMP conjugate (Figure 3A). The cellular (or sample cAMP) competes with the cAMP conjugate for binding to the antibody. Detection of the labeled cAMP conjugate is then determined by a variety of methods including enzymatic reactions and Förster resonance energy transfer (FRET). As an example, the HitHunter enzymatic assay (DiscoveryX) uses fragment complementation technology in which one fragment of the $\beta$-galactosidase enzyme is conjugated to cAMP ( $\beta$-gal-cAMP) (Figure 3A) [51,67]. In the presence of high levels of cellular cAMP, the anticAMP Ab becomes saturated, allowing the $\beta$-gal-cAMP complex to complement with a second $\beta$-galactosidase enzyme fragment and form an active enzyme. The active $\beta$-galactosidase enzyme then hydrolyzes a substrate to produce a colorimetric or chemiluminescent signal that is directly proportional to the amount of cellular cAMP.

While commercial kits using a cAMP conjugate provide a reliable and quantitative assay for measuring cAMP, they are relatively expensive, time consuming and involve postexperimental analysis. In contrast, cellular expression of cAMP biosensors provides a more rapid and cost effective approach that measures intracellular cAMP in living cells. One current protocol involves expressing cyclic nucleotide-gated (CNG) channels in cells expressing the CB1 receptor (Figure 3B) [72]. As the name implies CNG channels open during elevations in intracellular cyclic nucleotides [73,74]. CNG channels containing the double mutation C460W and E583M have a high affinity for cAMP but are relatively insensitive to cGMP [73,74]. CNG channels are nonselective cation channels that allow the permeation of $\mathrm{Na}^{+}, \mathrm{K}^{+}$and $\mathrm{Ca}^{2+}$ through the cell membrane. Thus, increases in intracellular cAMP open the C460W/E583M CNG channel allowing $\mathrm{Ca}^{2+}$ flux into the cell. The increased $\mathrm{Ca}^{2+}$ can then be quantified using a $\mathrm{Ca}^{2+}$-sensitive fluorescent dye (e.g., Furo-2, Fluo-4, etc.). Alternatively, cAMP levels are measured in real-time in CB1 receptor cells using a bioluminescence resonance energy transfer (BRET) assay (Figure 3C) [48,50,52]. BRET involves the transfer of energy from a donor luminescence enzyme to an acceptor fluorophore. BRET occurs when the luminescent donor is in close proximity to the acceptor fluorophore. In this protocol, cells are transfected with a cAMP BRET biosensor consisting of a cAMP binding protein (EPAC) coupled to a BRET pair: Renilla luciferase (RLuc) (the donor) and yellow fluorescent protein (YFP) (the acceptor) [75]. Binding of cAMP to EPAC causes a change in the conformation of the protein resulting in a separation of RLuc and YFP [75]. As a result, increases in intracellular cAMP result in a loss of BRET intensity. Finally, GloSensor technology (Promega) uses a mutant form of Photinus pyralis luciferase into which a cAMP-binding protein has been inserted [47,49]. Binding of cAMP to the construct causes a conformational change leading to increased luciferase activity and an increased light signal. One major limitation of the cAMP BRET, GloSensor and CNG channel assays is that they require successful cell transfection, making them largely limited for use with heterologous HEK293 and CHO cell lines. 


\section{3. $\beta$-Arrestin Recruitment}

There are two $\beta$-arrestin isoforms, $\beta$ arr1 and $\beta$ arr2, found in CB1 receptor-expressing neurons $[33,34]$. It is speculated that $\beta$ arr 2 induces $C B 1$ receptor desensitization and internalization while $\beta$ arr1 activates MAPKs (see below) [35]. The PathHunter (DiscoveryX) and NanoBit (Promega) assays have been widely used to study CB1 receptor recruitment of $\beta$-arrestins. Similar to the HitHunter cAMP assay, both the PathHunter and NanoBiT technologies use enzyme fragment complementation to measure CB1 receptor- $\beta$-arrestin recruitment (Figure 3A) [61,63]. With the PathHunter assay, the CB1 receptor is tagged with one fragment of the $\beta$-galactosidase enzyme while $\beta$ arr2 is tagged with the complementary $\beta$-galactosidase fragment. Following binding of the SC to the CB1 receptor and recruitment of $\beta$ arr2, a fully functional $\beta$-galactosidase enzyme is formed. With the NanoBit assay system both $\beta$ arr2 and the CB1 receptor are fused to an inactive fragment of nanoluciferase termed small BIT and large BIT. In this case, interaction of the complementary nanoluciferase fragments results in a functional enzyme that produces a luminescent signal. One caveat in the use of these technologies is that tagging of $\beta$ arr2 and the CB1 receptor may affect their trafficking and/or function following heterologous cell expression.

\subsection{GIRK Channel Activation}

Binding of SCs to the CB1 receptor stimulates the dissociation of the $\beta \gamma$ subunits of $G_{i}$ from the $\alpha$ subunit. In neuronal tissues, $G_{i} \beta \gamma$ then activates GIRK (Kir3.1/3.2) channels causing a cellular efflux of $\mathrm{K}^{+}$and a concomitant decrease in the cell resting membrane potential (Figure 2) [10,76]. Therefore, cellular expression of the CB1 receptor and GIRK channels can be used to monitor SC-mediated $\mathrm{G}_{i}$ protein stimulation. In these so-called hyperpolarization assays [56,77] cells are loaded with a membrane potential-sensitive dye (MPSD) which distributes across the plasma membrane (Figure 3D). The MPSD molecules inside the cells become strongly fluorescent upon binding to intracellular proteins and other cytoplasmic components. SC activation of the GIRK channels causes the resting membrane potential of the cell to hyperpolarize (more negative potential). As a result, the MPSD molecules redistribute across the plasma membrane with a resulting decrease in the fluorescent signal. New proprietary MPSDs produced by Molecular Devices (FLIPR Membrane Potential Assay kit) and Anaspec (HLB 021-152) provide faster response times and larger fluorescent signals than older oxonol MPSDs. While hyperpolarization assays provide a convenient and inexpensive approach for measuring CB1 receptor- $G_{i}$ signaling, they represent an indirect measure of $G_{i}$ activity when contrasted to the $\left[{ }^{35} \mathrm{~S}\right] \mathrm{GTP} \gamma \mathrm{S}$ binding assay.

\subsection{MAPK Signaling}

Extracellular signal-regulated kinase 1 and 2 (ERK1/2) are serine/threonine protein kinases that serve as essential components of the MAPK signal transduction pathway. CB1 receptor stimulation of $\mathrm{G}_{\mathrm{i}}$ and $\beta$-arrestin results in the phosphorylation of both p42 (pERK2) and p44 (pERK1) (Figure 2) [36]. Traditionally, measurement of p-ERK1/2 was carried out using immunoblot analysis of cell lysates with p-ERK1/2 specific antibodies. The AlphaScreen SureFire p-ERK assay kit (Perkin Elmer \& TGR Biosciences) is an immuno-sandwich capture technology that has gained popularity in recent years [78]. The kit utilizes donor and acceptor Alpha beads that are each coated to specifically capture antibodies in the assay. One antibody is specific for the phosphorylation site on p-ERK while the other is a biotinylated antibody specific for another epitope on the protein. In the presence of p-ERK the antibodies bring the donor and acceptor beads in close proximity generating a chemiluminescence signal with an intensity that is proportional to the amount of p-ERK. When compared with immunoblot analysis, one major advantage of the AlphaScreen SureFire assay is that allows p-ERK detection in a multi-well plate format. Thus, this technology can be utilized for high throughput screening of cannabinoids that stimulate ERK1/2. 


\section{Summary of SC Molecular Pharmacology}

Table 1 summarizes the effects of SCs on cell signaling pathways with $\mathrm{EC}_{50} \mathrm{~s}$ and $\mathrm{E}_{\max } \mathrm{S}$ determined using the assays described in Section 4. Like other GPCRs, the CB1 receptor undergoes conformational changes upon ligand binding that are essential for activation of the $G_{i}$ pathway $[79,80]$. These conformational changes are thought to be facilitated by a conserved network of noncovalent interactions, and that these allosteric rearrangements define activation pathways. Such activation pathways include small groups of adjoining amino acids within the transmembrane domains (TM) that include toggle switches $[79,80]$. Cryoelectron microscopy (cyro-EM) studies suggest that differences in cannabinoid interaction with the CB1 receptor toggle switch (consisting of residues F200 and W356 in the TM2/TM6 binding pocket) may contribute to different ligand efficacies [80]. For example, strong aromatic interactions of the indazole ring of the SC MDMB-FUBINACA (FUB) with the toggle switch stabilizes the active conformation of the receptor and results in the high efficacy of this ligand (Figure 1; Table 1) [80]. In contrast, the lack of toggle switch interaction may explain why THC acts as a partial agonist at the CB1 receptor [80].

While the results summarized in Table 1 were obtained using various cell systems, experimental methods and transgene constructs, some important generalizations can be drawn from the data. First and foremost, newer indole and indazole carboxylate SCs such as AB-FUBINACA, 5F-MDMB PINACA and 5F-MDMB PICA are far more potent than older SCs including WIN 55,212, JWH-018 and XLR-11. For some of these compounds $\mathrm{EC}_{50}$ values measured using GloSensor (cAMP), BRET (cAMP), MPSD (GIRK channel) and NanoBiT ( $\beta$-arrestin) assays are 100-fold lower than those measured for naphtholylindole and tetramethylcyclopropyl SCs. Secondly, SCs such as JWH-018, 5F-AMB-PINACA and MDMB-FUBINACA display roughly equal potencies in stimulating $G_{i}$ and recruiting $\beta a r r 2$. In contrast, cannabinoids such as CP-55,940 (Table 1), PNR-420 and THC are reported to have less activity in $\beta$-arrestin assays when compared with cAMP assays [52,62]. Based on these, and previously reported differences in SC cell signaling profiles, operational models have been applied to calculate ligand bias factors [54,81]. In this analysis, transduction coefficients are calculated from the $\mathrm{EC}_{50} \mathrm{~s}$ and $\mathrm{E}_{\max } \mathrm{S}$ measured using various signaling assays and compared with a reference compound (such as WIN $55,212-2)[54,81]$. Operational analysis eliminates errors that arise from differences in CB1 receptor expression levels, experimental cell type and other confounding factors. As anticipated, bias factor analysis supports the hypothesis that THC and some SCs act preferentially on the $\mathrm{G}_{i}$ pathway while other SCs, including indazole carboxylates, are balanced in their signaling actions [52,62].

Not only do SCs differ in their abilities to activate CB1 receptor $G_{i}$ and $\beta$-arrestin pathways, but they can also couple to other $G$ proteins within the same cell. While the $C B 1$ receptor predominately couples to $G_{i}$, signaling through $G_{s}$ and $G_{q}$ has also been reported [31,32]. In the presence of pertussis toxin to inhibit $G_{i} / G_{0}$, high concentrations of SCs such as WIN 55,212-2, CP-55,940, JWH-018 and AB-FUBINACA increase cAMP levels above those produced by forskolin $[48,50]$. Interestingly, increases in CAMP are not observed with THC under these conditions, again implying that ligand-receptor interactions modulate $G$ protein coupling $[48,50]$. In addition to stimulating $G_{i}$ and $G_{s}$, WIN $55,212-2$ acts via the CB1 receptor/ $\mathrm{G}_{\mathrm{q}} /$ phospholipase $C$ pathway to increase intracellular $\mathrm{Ca}^{2+}$ levels in HEK293 cells and cultured hippocampal neurons [32]. Although endocannabinoids such AEA [82] and $\mathrm{N}$-arachidonoyldopamine (NADA) [83] are also known to stimulate intracellular $\mathrm{Ca}^{2+}$ release, the effect of newer classes of SCs on Gq is currently unknown.

\section{Conclusions}

This review has provided a description of cell-based assays used in the characterization of CB1 receptor-mediated signaling and an overview of SC molecular actions. SCs pose a significant public health risk and represent challenges for hospital ERs because of their wide range of adverse effects. Since 2010 the EMCDDA has reported an alarming increase in the number of SCs on the NPS market [3]. Therefore, it is critical to understand how cannabinoid-CB1 receptor interactions and subsequent cell signaling events bring about both desired and harmful effects. As postulated 
for $\mu$-opioid receptor agonists, SC-mediated recruitment of $\beta$ arr1 and $\beta$ arr2 may contribute to SC toxicity [52,62]. The introduction of new techniques for assessing biased agonism, as well as allosteric and off-target actions of cannabinoids, will be essential in addressing these challenges.

Funding: This work was supported by US Public Health Service award NS-071530 and National Science Foundation award CBET-1606882 to KBW.

Conflicts of Interest: The authors declare no conflict of interest. The funders had no role in the design of the study; in the collection, analyses, or interpretation of data; in the writing of the manuscript, or in the decision to publish the results.

\section{Abbreviations}

$\begin{array}{ll}\text { SC } & \text { Synthetic cannabinoid } \\ \text { THC } & \text { Tetrahydrocannabinol } \\ \text { GIRK } & \text { G protein-gated inward rectifier } \mathrm{K}^{+} \\ \text {SAR } & \text { Structure versus activity relationship } \\ \text { GPCR } & \text { G protein-coupled receptor } \\ \text { EMCDDA } & \text { European Monitoring Centre for Drugs \& Drug Addiction } \\ \text { TRP } & \text { Transient receptor potential } \\ \text { ERK1/2 } & \text { Extracellular signal-regulated kinase 1/2 } \\ \text { AEA } & \text { Anandamide } \\ 2 \text { AG } & \text { 2-Arachidonoylglycerol } \\ \text { EC } 50 & \text { Half-maximal effective concentration } \\ \text { Emax } & \text { Maximal response } \\ \text { FRET } & \text { Förster resonance energy transfer } \\ \text { CNG } & \text { Cyclic nucleotide-gated } \\ \text { BRET } & \text { Bioluminescence resonance energy transfer } \\ \text { MPSD } & \text { Membrane potential-sensitive dye } \\ \text { TM } & \text { Transmembrane domains }\end{array}$

\section{References}

1. Ford, B.M.; Tai, S.; Fantegrossi, W.E.; Prather, P.L. Synthetic pot: Not your grandfather's marijuana. Trends. Pharmacol. Sci. 2017, 38, 257-276. [CrossRef]

2. Worob, A.; Wenthur, C. DARK classics in chemical neuroscience: Synthetic cannabinoids (Spice/K2). ACS Chem. Neurosci. 2019. [CrossRef]

3. Potts, A.J.; Cano, C.; Thomas, S.H.L.; Hill, S.L. Synthetic cannabinoid receptor agonists: Classification and nomenclature. Clin. Toxicol. 2020, 58, 82-98. [CrossRef]

4. Gaoni, Y.; Mechoulam, R. The isolation and structure of delta-1-tetrahydrocannabinol and other neutral cannabinoids from hashish. J. Am. Chem. Soc. 1971, 93, 217-224. [CrossRef]

5. Devane, W.A.; Hanus, L.; Breuer, A.; Pertwee, R.G.; Stevenson, L.A.; Griffin, G.; Gibson, D.; Mandelbaum, A.; Etinger, A.; Mechoulam, R. Isolation and structure of a brain constituent that binds to the cannabinoid receptor. Science 1992, 258, 1946-1949. [CrossRef] [PubMed]

6. Matsuda, L.A.; Lolait, S.J.; Brownstein, M.J.; Young, A.C.; Bonner, T.I. Structure of a cannabinoid receptor and functional expression of the cloned cDNA. Nature 1990, 346, 561-564. [CrossRef] [PubMed]

7. Schlicker, E.; Kathmann, M. Modulation of transmitter release via presynaptic cannabinoid receptors. Trends Pharmacol. Sci. 2001, 22, 565-572. [CrossRef]

8. Tsou, K.; Brown, S.; Sañudo-Peña, M.C.; Mackie, K.; Walker, J.M. Immunohistochemical distribution of cannabinoid CB1 receptors in the rat central nervous system. Neuroscience 1998, 83, 393-411. [CrossRef]

9. Howlett, A.C.; Qualy, J.M.; Khachatrian, L.L. Involvement of Gi in the inhibition of adenylate cyclase by cannabimimetic drugs. Mol. Pharmacol. 1986, 29, 307-313. [PubMed]

10. Mackie, K.; Lai, Y.; Westenbroek, R.; Mitchell, R. Cannabinoids activate an inwardly rectifying potassium conductance and inhibit Q-type calcium currents in AtT20 cells transfected with rat brain cannabinoid receptor. J. Neurosci. 1995, 15, 6552-6561. [CrossRef] [PubMed] 
11. Szabo, B.; Schlicker, E. Effects of Cannabinoids on Neurotransmission. In Cannabinoids; Pertwee, R.G., Ed.; Springer Berlin Heidelberg: Berlin, Heidelberg, 2005; pp. 327-365.

12. Compton, D.R.; Gold, L.H.; Ward, S.J.; Balster, R.L.; Martin, B.R. Aminoalkylindole analogs: Cannabimimetic activity of a class of compounds structurally distinct from delta 9-tetrahydrocannabinol. J. Pharmacol. Exp. Ther. 1992, 263, 1118-1126. [PubMed]

13. Wiley, J.L.; Marusich, J.A.; Huffman, J.W. Moving around the molecule: Relationship between chemical structure and in vivo activity of synthetic cannabinoids. Life Sci. 2014, 97, 55-63. [CrossRef] [PubMed]

14. Wiley, J.L.; Compton, D.R.; Dai, D.; Lainton, J.A.; Phillips, M.; Huffman, J.W.; Martin, B.R. Structure-activity relationships of indole- and pyrrole-derived cannabinoids. J. Pharmacol. Exp. Ther. 1998, 285, 995-1004.

15. Wiley, J.L.; Marusich, J.A.; Thomas, B.F. Combination Chemistry: Structure-Activity Relationships of Novel Psychoactive Cannabinoids. In Neuropharmacology of New Psychoactive Substances (NPS): The Science Behind the Headlines; Baumann, M.H., Glennon, R.A., Wiley, J.L., Eds.; Springer International Publishing: Cham, Switzerland, 2017; pp. 231-248.

16. Alexandre, J.; Carmo, H.; Carvalho, F.; Silva, J.P. Synthetic cannabinoids and their impact on neurodevelopmental processes. Addict. Biol. 2020, 25, e12824. [CrossRef] [PubMed]

17. Akram, H.; Mokrysz, C.; Curran, H.V. What are the psychological effects of using synthetic cannabinoids? A systematic review. J. Psychopharmacol. 2019, 33, 271-283. [CrossRef] [PubMed]

18. Alam, R.M.; Keating, J.J. Adding more "spice" to the pot: A review of the chemistry and pharmacology of newly emerging heterocyclic synthetic cannabinoid receptor agonists. Drug Test. Anal. 2020, 12, 297-315. [CrossRef] [PubMed]

19. D’Ambra, T.E.; Estep, K.G.; Bell, M.R.; Eissenstat, M.A.; Josef, K.A.; Ward, S.J.; Haycock, D.A.; Baizman, E.R.; Casiano, F.M.; Beglin, N.C.; et al. Conformationally restrained analogs of pravadoline: Nanomolar potent, enantioselective, (aminoalkyl)indole agonists of the cannabinoid receptor. J. Med. Chem. 1992, 35, 124-135. [CrossRef]

20. Huffman, J.W.; Zengin, G.; Wu, M.J.; Lu, J.; Hynd, G.; Bushell, K.; Thompson, A.L.S.; Bushell, S.; Tartal, C.; Hurst, D.P.; et al. Structure-activity relationships for 1-alkyl-3-(1-naphthoyl)indoles at the cannabinoid CB1 and CB2 receptors: Steric and electronic effects of naphthoyl substituents. New highly selective CB2 receptor agonists. Bioorg. Med. Chem. 2005, 13, 89-112. [CrossRef]

21. Atwood, B.K.; Huffman, J.; Straiker, A.; Mackie, K. JWH018, a common constituent of "Spice" herbal blends, is a potent and efficacious cannabinoid CB1 receptor agonist. Br. J. Pharmacol. 2010, 160, 585-593. [CrossRef]

22. Ganesh, A.T.; Spyros, P.N.; Makriyannis, A. CB1 cannabinoid receptor ligands. Mini. Rev. Med. Chem. 2005, 5, 631-640.

23. Howlett, A.C.; Champion, T.M.; Wilken, G.H.; Mechoulam, R. Stereochemical effects of 11-OH-delta-8tetrahydrocannabinol-dimethylheptyl to inhibit adenylate cyclase and bind to the cannabinoid receptor. Neuropharmacology 1990, 29, 161-165. [CrossRef]

24. Leker, R.R.; Shohami, E.; Abramsky, O.; Ovadia, H. Dexanabinol (HU-211); a novel neuroprotective drug in experimental focal cerebral ischemia. J. Neurol. Sci. 1999, 162, 114-119. [CrossRef]

25. Doi, T.; Tagami, T.; Takeda, A.; Asada, A.; Sawabe, Y. Evaluation of carboxamide-type synthetic cannabinoids as $\mathrm{CB}(1) / \mathrm{CB}(2)$ receptor agonists: Difference between the enantiomers. Forensic Toxicol. 2018, 36, 51-60. [CrossRef] [PubMed]

26. Antonides, L.H.; Cannaert, A.; Norman, C.; Vives, L.; Harrison, A.; Costello, A.; Daeid, N.N.; Stove, C.P.; Sutcliffe, O.B.; McKenzie, C. Enantiospecific synthesis, chiral separation, and biological activity of four indazole-3-carboxamide-type synthetic cannabinoid receptor agonists and their detection in seized drug samples. Front. Chem. 2019, 7, 321. [CrossRef]

27. Makriyannis, A.; Deng, H. U.S. Patent US00/28832 1-25, 26 April 2001.

28. Banister, S.D.; Stuart, J.; Kevin, R.C.; Edington, A.; Longworth, M.; Wilkinson, S.M.; Beinat, C.; Buchanan, A.S.; Hibbs, D.E.; Glass, M.; et al. Effects of bioisosteric fluorine in synthetic cannabinoid designer drugs JWH-018, AM-2201, UR-144, XLR-11, PB-22, 5F-PB-22, APICA, and STS-135. ACS Chem. Neurosci. 2015, 6, 1445-1458. [CrossRef]

29. Hua, T.; Vemuri, K.; Pu, M.; Qu, L.; Han, G.W.; Wu, Y.; Zhao, S.; Shui, W.; Li, S.; Korde, A.; et al. Crystal structure of the human cannabinoid receptor CB1. Cell 2016, 167, 750-762. [CrossRef]

30. Shao, Z.; Yin, J.; Chapman, K.; Grzemska, M.; Clark, L.; Wang, J.; Rosenbaum, D.M. High-resolution crystal structure of the human CB1 cannabinoid receptor. Nature 2016, 540, 602-606. [CrossRef] 
31. Glass, M.; Northup, J.K. Agonist selective regulation of $G$ proteins by cannabinoid $\mathrm{CB}(1)$ and $\mathrm{CB}(2)$ receptors. Mol. Pharmacol. 1999, 56, 1362-1369. [CrossRef]

32. Lauckner, J.E.; Hille, B.; Mackie, K. The cannabinoid agonist WIN 55,212-2 increases intracellular calcium via CB1 receptor coupling to $\mathrm{G}_{\mathrm{q}} / 11 \mathrm{G}$ proteins. Proc. Natl. Acad. Sci. USA 2005, 102, 19144-19149. [CrossRef]

33. Jin, W.; Brown, S.; Roche, J.P.; Hsieh, C.; Celver, J.P.; Kovoor, A.; Chavkin, C.; Mackie, K. Distinct domains of the CB1 cannabinoid receptor mediate desensitization and internalization. J. Neurosci. 1999, 19, 3773-3780. [CrossRef]

34. Kouznetsova, M.; Kelley, B.; Shen, M.; Thayer, S.A. Desensitization of cannabinoid-mediated presynaptic inhibition of neurotransmission between rat hippocampal neurons in culture. Mol. Pharmacol. 2002, 61, 477-485. [CrossRef] [PubMed]

35. Ahn, K.H.; Mahmoud, M.M.; Shim, J.Y.; Kendall, D.A. Distinct roles of $\beta$-arrestin 1 and $\beta$-arrestin 2 in ORG27569-induced biased signaling and internalization of the cannabinoid receptor 1 (CB1). J. Biol. Chem. 2013, 288, 9790-9800. [CrossRef] [PubMed]

36. Bouaboula, M.; Poinot-Chazel, C.; Bourrié, B.; Canat, X.; Calandra, B.; Rinaldi-Carmona, M.; Fur, G.L.; Casellas, P. Activation of mitogen-activated protein kinases by stimulation of the central cannabinoid receptor CB1. Biochem. J. 1995, 312, 637-641. [CrossRef] [PubMed]

37. Galve-Roperh, I.; Rueda, D.; Gómez del Pulgar, T.; Velasco, G.; Guzmán, M. Mechanism of extracellular signal-regulated kinase activation by the CB(1) cannabinoid receptor. Mol. Pharmacol. 2002, 62, 1385-1392. [CrossRef]

38. Derkinderen, P.; Valjent, E.; Toutant, M.; Corvol, J.C.; Enslen, H.; Ledent, C.; Trzaskos, J.; Caboche, J.; Girault, J.A. Regulation of extracellular signal-regulated kinase by cannabinoids in hippocampus. J. Neurosci. 2003, 23, 2371-2382. [CrossRef]

39. Smart, D.; Gunthorpe, M.J.; Jerman, J.C.; Nasir, S.; Gray, J.; Muir, A.I.; Chambers, J.K.; Randall, A.D.; Davis, J.B. The endogenous lipid anandamide is a full agonist at the human vanilloid receptor (hVR1). Br. J. Pharmacol. 2000, 129, 227-230. [CrossRef]

40. De Petrocellis, L.; Ligresti, A.; Moriello, A.S.; Allarà, M.; Bisogno, T.; Petrosino, S.; Stott, C.G.; Marzo, V.D. Effects of cannabinoids and cannabinoid-enriched Cannabis extracts on TRP channels and endocannabinoid metabolic enzymes. Br. J. Pharmacol. 2011, 163, 1479-1494. [CrossRef]

41. Kohno, M.; Hasegawa, H.; Inoue, A.; Muraokaa, M.; Miyazaki, T.; Oka, K.; Yasukawa, M. Identification of $\mathrm{N}$-arachidonylglycine as the endogenous ligand for orphan G-protein-coupled receptor GPR18. Biochem. Biophys. Res. Comm. 2006, 347, 827-832. [CrossRef]

42. Ryberg, E.; Larsson, N.; Sjõgren, S.; Hjorth, S.; Hermansson, N.O.; Leonova, J.; Elebring, T.; Nilsson, K.; Drmota, T.; Greasley, P.J. The orphan receptor GPR55 is a novel cannabinoid receptor. Br. J. Pharmacol. 2007, 152, 1092-1101. [CrossRef]

43. Reiter, E.; Ahn, S.; Shukla, A.K.; Lefkowitz, R.J. Molecular mechanism of $\beta$-arrestin-biased agonism at seven-transmembrane receptors. Annu. Rev. Pharmacol. Toxicol 2012, 52, 179-197. [CrossRef]

44. Schmid, C.L.; Kennedy, N.M.; Ross, N.C.; Lovell, K.M.; Yue, Z.; Morgenweck, J.; Cameron, M.D.; Bannister, T.D.; Bohn, L.M. Bias factor and therapeutic window correlate to predict safer opioid analgesics. Cell 2017, 171, 1165-1175. [CrossRef] [PubMed]

45. Chen, X.T.; Pitis, P.; Liu, G.; Yuan, C.; Gotchev, D.; Cowan, C.L.; Rominger, D.H.; Koblish, M.; Dewire, S.M.; Crombie, A.L.; et al. Structure-activity relationships and discovery of a $\mathrm{G}$ protein biased m-opioid receptor ligand, [(3-methoxythiophen-2-yl)methyl](\{2-[(9R)-9-(pyridin-2-yl)-6-oxaspiro-[4.5]decan-9-yl]ethyl $\})$ amine (TRV130), for the treatment of acute severe pain. J. Med. Chem. 2013, 56, 8019-8031. [CrossRef] [PubMed]

46. Gamage, T.F.; Farquhar, C.E.; McKinnie, R.J.; Kevin, R.C.; McGregor, I.S.; Trudell, M.L.; Wiley, J.L.; Thomas, B.F. Synthetic cannabinoid hydroxypentyl metabolites retain efficacy at human cannabinoid receptors. J. Pharmacol. Exp. Ther. 2019, 368, 414-422. [CrossRef] [PubMed]

47. Costain, W.J.; Tauskela, J.S.; Rasquinha, I.; Comas, T.; Hewitt, M.; Marleau, V.; Soo, E.C. Pharmacological characterization of emerging synthetic cannabinoids in HEK293T cells and hippocampal neurons. Eur. J. Pharmacol. 2016, 786, 234-245. [CrossRef] [PubMed]

48. Sachdev, S.; Banister, S.D.; Santiago, M.; Bladen, C.; Kassiou, M.; Connor, M. Differential activation of G protein-mediated signaling by synthetic cannabinoid receptor agonists. Pharmacol. Res. Perspect. 2020, 8 , e00566. [CrossRef] 
49. Costain, W.J.; Rasquinha, I.; Comas, T.; Hewitt, M.; Aylsworth, A.; Rouleau, Y.; Marleau, V.; Soo, E.C.; Tauskela, J.S. Analysis of the pharmacological properties of JWH-122 isomers and THJ-2201, RCS-4 and AB-CHMINACA in HEK293T cells and hippocampal neurons. Eur. J. Pharmacol. 2018, 823, 96-104. [CrossRef]

50. Patel, M.; Manning, J.J.; Finlay, D.B.; Javitch, J.A.; Banister, S.D.; Grimsey, N.L.; Glass, M. Signalling profiles of a structurally diverse panel of synthetic cannabinoid receptor agonists. Biochem. Pharmacol. 2020, 175, 113871. [CrossRef]

51. Yao, B.B.; Hsieh, G.C.; Frost, J.M.; Fan, Y.; Garrison, T.R.; Daza, A.V.; Grayson, G.K.; Zhu, C.Z.; Pai, M.; Chandran, P.; et al. In vitro and in vivo characterization of A-796260: A selective cannabinoid CB2 receptor agonist exhibiting analgesic activity in rodent pain models. Br. J. Pharmacol. 2008, 153, 390-401. [CrossRef]

52. Finlay, D.B.; Manning, J.J.; Ibsen, M.S.; Macdonald, C.E.; Patel, M.; Javitch, J.A.; Banister, S.D.; Glass, M. Do toxic synthetic cannabinoid receptor agonists have signature in vitro activity profiles? A case study of AMB-FUBINACA. ACS Chem. Neurosci. 2019, 10, 4350-4360. [CrossRef]

53. Soethoudt, M.; Grether, U.; Fingerle, J.; Grim, T.W.; Fezza, F.; Petrocellis, L.; Ullmer, C.; Rothenhäusler, B.; Perret, C.; Gils, N.; et al. Cannabinoid CB2 receptor ligand profiling reveals biased signalling and off-target activity. Nat. Commun. 2017, 8, 13958. [CrossRef]

54. Laprairie, R.B.; Bagher, A.M.; Kelly, M.E.M.; Dupré, D.J.; Denovan-Wright, E.M. Type 1 cannabinoid receptor ligands display functional selectivity in a cell culture model of striatal medium spiny projection neurons. J. Biol. Chem. 2014, 289, 24845-24862. [CrossRef] [PubMed]

55. Banister, S.D.; Wilkinson, S.M.; Longworth, M.; Stuart, J.; Apetz, N.; English, K.; Brooker, L.; Goebe, C.; Hibbs, D.E.; Glass, M.; et al. The synthesis and pharmacological evaluation of adamantane-derived indoles: Cannabimimetic drugs of abuse. ACS Chem. Neurosci. 2013, 4, 1081-1092. [CrossRef] [PubMed]

56. Andersen, H.K.; Piroli, G.; Walsh, K.B. A real time screening assay for cannabinoid CB1 receptor-mediated signaling. J. Pharmacol. Toxicol. Methods 2018, 94, 44-49. [CrossRef] [PubMed]

57. Marusich, J.A.; Wiley, J.L.; Lefever, T.W.; Patel, P.R.; Thomas, B.F. Finding order in chemical chaos-Continuing characterization of synthetic cannabinoid receptor agonists. Neuropharmacology 2018, 134, 73-81. [CrossRef]

58. Gatch, M.B.; Forster, M.J. D9-Tetrahydrocannabinol-like effects of novel synthetic cannabinoids in mice and rats. Psychopharmacology 2016, 233, 1901-1910. [CrossRef]

59. Banister, S.D.; Moir, M.; Stuart, J.; Kevin, R.C.; Wood, K.E.; Longworth, M.; Wilkinson, S.M.; Beinat, C.; Buchanan, A.S.; Glass, M.; et al. Pharmacology of Indole and Indazole Synthetic Cannabinoid Designer Drugs AB-FUBINACA, ADB-FUBINACA, AB-PINACA, ADB-PINACA, 5F-AB-PINACA, 5F-ADB-PINACA, ADBICA, and 5F-ADBICA. ACS Chem. Neurosci. 2015, 6, 1546-1559. [CrossRef]

60. Longworth, M.; Connor, M.; Banister, S.D.; Kassiou, M. Synthesis and pharmacological profiling of the metabolites of synthetic cannabinoid drugs APICA, STS-135, ADB-PINACA, and 5F-ADB-PINACA. ACS Chem. Neurosci. 2017, 8, 1673-1680. [CrossRef]

61. Noble, C.; Cannaert, A.; Linnet, K.; Stove, C.P. Application of an activity-based receptor bioassay to investigate the in vitro activity of selected indole- and indazole-3-carboxamide-based synthetic cannabinoids at CB1 and CB2 receptors. Drug Test. Anal. 2019, 11, 501-511. [CrossRef]

62. Ford, B.M.; Franks, L.N.; Tai, S.; Fantegrossi, W.E.; Stahl, E.L.; Berquist, M.D.; Cabanlong, C.V.; Wilson, C.D.; Penthala, N.R.; Crooks, P.A.; et al. Characterization of structurally novel G protein biased CB1 agonists: Implications for drug development. Pharmacol. Res. 2017, 125, 161-177. [CrossRef]

63. Wouters, E.; Mogler, L.; Cannaert, A.; Auwärter, V.; Stov, C. Functional evaluation of carboxy metabolites of synthetic cannabinoid receptor agonists featuring scaffolds based on L-valine or L-tert-leucine. Drug Test. Anal. 2019, 11, 1183-1191. [CrossRef]

64. Cannaert, A.; Storme, J.; Franz, F.; Auwärter, V.; Stov, C.P. Detection and activity profiling of synthetic cannabinoids and their metabolites with a newly developed bioassay. Anal. Chem. 2016, 88, 11476-11485. [CrossRef] [PubMed]

65. Cannaert, A.; Franz, F.; Auwärter, V.; Stove, C.P. Activity-based detection of consumption of synthetic cannabinoids in authentic urine samples using a stable cannabinoid reporter system. Anal. Chem. 2017, 89, 9527-9536. [CrossRef] [PubMed]

66. Wiley, J.L.; Marusich, J.A.; Lefever, T.W.; Antonazzo, K.R.; Wallgren, M.T.; Cortes, R.A.; Patel, P.R.; Grabenauer, M.; Moore, K.N.; Thomas, B.F. AB-CHMINACA, AB-PINACA, and FUBIMINA: Affinity and potency of novel synthetic cannabinoids in producing D9-tetrahydrocannabinol-like effects in mice. J. Pharmacol. Exp. Ther. 2015, 354, 328-329. [CrossRef] [PubMed] 
67. Franz, F.; Angerer, V.; Moosmann, B.; Auwärter, V. Phase I metabolism of the highly potent synthetic cannabinoid MDMB-CHMICA and detection in human urine samples. Drug Test. Anal. 2017, 9, 744-753. [CrossRef] [PubMed]

68. Canazza, I.; Ossato, A.; Vincenzi, F.; Gregori, A.; Rosa, F.D.; Nigro, F.; Rimessi, A.; Pinton, P.; Varani, K.; Borea, P.A.; et al. Pharmaco-toxicological effects of the novel third-generation fluorinate synthetic cannabinoids, 5F-ADBINACA, AB-FUBINACA, and STS-135 in mice. In vitro and in vivo studies. Hum. Psychopharmacol. 2017, 32, e2601. [CrossRef] [PubMed]

69. Gamage, T.F.; Farquhar, C.E.; Lefever, T.W.; Marusich, J.A.; Kevin, R.C.; McGregor, I.S.; Wiley, J.L.; Thomas, B.F. Molecular and behavioral pharmacological characterization of abused synthetic cannabinoids MMB- and MDMB-FUBINACA, MN-18, NNEI, CUMYL-PICA, and 5-Fluoro-CUMYL-PICA. J. Pharmacol. Exp. Ther. 2018, 365, 437. [CrossRef]

70. Sittampalam, G.S. Enabling Drug Discovery Technologies for Regenerative Pharmacology. In Regenerative Pharmacology; Christ, G., Andersson, K., Eds.; Cambridge University Press: Cambridge, England, 2013; pp. 190-218.

71. Walsh, K.B. Targeting cardiac potassium channels for state-of-the-art drug discovery. Expert Opin. Drug Deliv. 2014, 10, 157-169. [CrossRef]

72. Presley, C.S.; Abidi, A.H.; Moore, B.M. Optimization of cAMP fluorescence dataset from ACTOne cannabinoid receptor 1 cell line. Data Brief. 2016, 7, 1118-1123. [CrossRef]

73. Rich, T.C.; Tse, T.E.; Rohan, J.G.; Schaack, J.; Karpena, J.W. In vivo assessment of local phosphodiesterase activity using tailored cyclic nucleotide-gated channels as cAMP sensors. J. Gen. Physiol. 2001, 118, 63-78. [CrossRef]

74. Rich, T.C.; Xin, W.; Leavesley, S.J.; Taylor, M.S. Channel-Based Reporters for cAMP Detection. In $c A M P$ Signaling: Methods and Protocols; Zaccolo, M., Ed.; Springer: New York, NY, USA, 2015; pp. 71-84.

75. Cheng, Z.J.; Miller, L.J. Agonist-dependent dissociation of oligomeric complexes of G protein-coupled cholecystokinin receptors demonstrated in living cells using bioluminescence resonance energy transfer. J. Biol. Chem. 2001, 276, 48040-48047. [CrossRef]

76. Walsh, K.B. Targeting GIRK channels for the development of new therapeutic agents. Front. Pharmacol. 2011, 2, 64. [CrossRef] [PubMed]

77. Cawston, E.E.; Redmond, W.J.; Breen, C.; Grimsey, N.L.; Connor, M.; Glass, M. Real-time characterization of cannabinoid receptor 1 allosteric modulators reveals novel mechanism of action. Br. J. Pharmacol. 2013, 170, 893-907. [CrossRef] [PubMed]

78. Finlay, D.B.; Cawston, E.E.; Grimsey, N.L.; Hunter, M.R.; Korde, A.; Vemuri, V.K.; Makriyannis, A.; Glass, M. $\mathrm{G} \alpha_{\mathrm{s}}$ signaling of the CB1 receptor and the influence of receptor number. Br. J. Pharmacol. 2017, 174, 2545-2562. [CrossRef] [PubMed]

79. Hua, T.; Vemuri, K.; Nikas, S.P.; Laprairie, R.B.; Wu, Y.; Qu, L.; Pu, M.; Korde, A.; Jiang, S.; Ho, J.H.; et al. Crystal structures of agonist-bound human cannabinoid receptor CB1. Nature 2017, 547, 468-471. [CrossRef] [PubMed]

80. Krishna Kumar, K.; Shalev-Benami, M.; Robertson, M.J.; Hu, H.; Banister, S.D.; Hollingsworth, S.A.; Latorraca, N.R.; Kato, H.E.; Hilger, D.; Maeda, S.; et al. Structure of a signaling cannabinoid receptor 1-G protein complex. Cell 2019, 176, 448-458. [CrossRef]

81. Kenakin, T.; Watson, C.; Muniz-Medina, V.; Christopoulos, A.; Novick, S. A simple method for quantifying functional selectivity and agonist bias. ACS Chem. Neurosci. 2012, 3, 193-203. [CrossRef] [PubMed]

82. De Petrocellis, L.; Marini, P.; Matias, I.; Moriello, A.S.; Starowicz, K.; Cristino, L.; Nigam, S.; Marzo, V.D. Mechanisms for the coupling of cannabinoid receptors to intracellular calcium mobilization in rat insulinoma $\beta$ cells. Exp. Cell Res. 2007, 313, 2993-3004. [CrossRef]

83. Redmond, W.J.; Cawston, E.E.; Grimsey, N.L.; Stuart, J.; Edington, A.R.; Glass, M.; Connor, M. Identification of $\mathrm{N}$-arachidonoyl dopamine as a highly biased ligand at cannabinoid CB1 receptors. Br. J. Pharmacol. 2016, 173, 115-127. [CrossRef]

(C) 2020 by the authors. Licensee MDPI, Basel, Switzerland. This article is an open access article distributed under the terms and conditions of the Creative Commons Attribution (CC BY) license (http://creativecommons.org/licenses/by/4.0/). 